\title{
Dominated Females: Lu Yin's The Heart of Women and the New Woman
}

\author{
Fang Wan $^{1}$ \\ ${ }^{1}$ Department of East Asian Languages and Cultures, SOAS University of London, London, United Kingdom \\ Correspondence: Fang Wan, Department of East Asian Languages and Cultures, SOAS University of London, \\ London, WC1H 0XG, United Kingdom.
}

Received: January 8, 2022

Accepted: February 15, 2022

Online Published: February 25, 2022

doi:10.5539/ach.v14n1p1

URL: https://doi.org/10.5539/ach.v14n1p1

\begin{abstract}
China's political, social and cultural environment during the 1920s and 1930s shaped the 'new woman' notion, which was a crucial dynamic of female liberation during the May Fourth era. In Lu Yin's novel The Heart of Women (Nüren de xin 女人的心), the image of new woman is secondary to the cause of China's modernisation in a male-dominated May Fourth discourse. This essay will explore this position from three perspectives. The construction of the new woman during the May Fourth era characterises the first point. The second is male-dominated discourse of modern identity and new woman in the May Fourth literature. Male lead in The Heart of Women is the third aspect.
\end{abstract}

Keywords: Lu Yin, New Woman, Modern Chinese Literature, May Fourth Era

\section{Introduction}

China's political, social and cultural environment during the 1920s and 1930s shaped the 'new woman' notion, which was a crucial dynamic of female liberation during the May Fourth era. Furthermore, a specific literary category developed partially due to the existence of the new woman concept, which profoundly affected literature. Previous studies mainly focus on the relationship between the concept of new woman and China's modernity, considering the paradigms of Chinese modernity and alterations in gender structure to investigate the new woman concept (Feng, 2004; Dooling, 2005). In recent research on new woman concept in Republican China, more attention has been paid to aesthetics of female body and femininity. Francesca Lawson (2014) discusses metaphysical femininity and feminine voice within the paradigm of new woman while Jun Lei (2015) investigates the degree to which the aesthetics of the female body changed in Republican China and how this change shaped the construction of the new woman concept.

Through analysing representative women's journals in Republican China and Lu Yin's 庐隐 works, this essay intends to elaborate the dominated position of male intellectuals in the construction of new woman concept during the May Fourth ear. Lu Yin, who adheres to May Fourth discourse throughout her time and primarily tackles the concept of the new woman within her books, is a foremost female author during the May Fourth period (Mao, 1982). However, Lu Yin's novel The Heart of Women (Nüren de xin 女人的心) does not provide examples of actual emancipated Chinese modern women; instead, the female character in this story is secondary to the cause of China's modernisation in a male-dominated May Fourth discourse. In this sense, a new male within a woman's body is being portrayed in this text, rather than a new woman. Three dynamics relating to this position will be explored in this study. The construction of the new woman during the May Fourth era is the first dynamic. Secondly, modern identity as portrayed in the May Fourth literature and this text's conceptualisation of the new woman are explored in terms of their correlation. The Heart of Women's male lead characterises the third point.

\section{The Construction of the New Woman in the May Fourth Period}

A number of academics encourage the emancipation of females in China during the May Fourth era. The concept of the new woman was developed at this point, although Chinese females' experiences and the perspectives of modern females in China were restricted as a consequence. How the development of a Chinese 'new woman' was restricted by male academics, as well as how China's modernisation initiatives undermined female liberation in China are the two aspects explored at this point. 
The development of China's concept of the new woman was regulated during the May Fourth period by male academics, who were the primary writers and editors of women's journals. For instance, The Ladies' Journal (Funï zazhi 妇女杂志), initially released on $5^{\text {th }}$ January 1915, was a foremost women's journal during the May Fourth era. Its first chief editor was Wang Yunzhang 王蕴章 (1884-1942); between 1915 and 1920 he was the sole editor (Mao, 1987). Although the chief editor for the second issue in 1916 was Hu Binxia 胡涁夏 (1888-1931) (The Ladies' Journal [TLJ], 1915), the chief editorship returned to Wang Yunzhang at the beginning of next year. Subsequently, the chief editor became Zhang Xichen 章锡琛 (1889-1969) in 1921. A further editor was employed in 1922, called Zhou Jianren 周建人 (1888-1984) (TLJ, 1922). In this period, The Ladies ' Journal became one of the most influential women's journals and contributed greatly to the development of China's new woman (Liu, 2008). Three individuals held the chief editorship position following the resignation of Zhang Xichen: between 1926's first issue and 1930's sixth issue the chief editor was Du Jiutian 杜就田; between 1930's seventh issue and 1931's third issue it was Ye Shengtao 叶圣陶 (1894-1988), while between 1931's fourth issue and 1931's twelfth issue it was Yang Runyu 杨润馀.

Yang Runyu and Hu Binxia were the sole women chief editors among them. Nevertheless, the actual chief editor was Wang Yunzhang while Hu Binxia was at The Ladies'Journal, with the latter not actually contributing to the editorial processes, as Xie Juceng 谢菊曾 argued (Xie, 1983). Although Yang Runyu took part in the editorial process, she only worked as chief editor for under a year. Moreover, when she was editor, The Ladies' Journal was not as influential as before (Zhang, 2016). Positioned as one of the May Fourth era's foremost journals for women, The Ladies' Journal explored the formulation of the new woman concept and the fundamental components of Chinese female's emancipation. Regardless, male academics comprised The Ladies' Journal's main writers and significant chief editors. Consequently, female perspectives and experiences were omitted from the development of the new woman category, which was created yet restricted by male authority. Ultimately, through involvement and writing in The Ladies' Journal, the development of the new woman concept in China was regulated by male academics.

Furthermore, May Fourth intellectuals subsumed Chinese women's emancipation under the project of national modernisation. The wellbeing of the nation was the common frame within which gender issues were discussed during the May Fourth era. Thus, China's strengthening and the education of women's children were the prominent concerns under the May Fourth period's approach to female education as a form of modern motherhood (Feng, 2004). Ultimately, on the basis of national wellbeing, the domestication of females was being encouraged through female education. Additionally, during the May Fourth era, involvement in the national workforce was also an opportunity extended equally to males and females as part of the latter's liberation. According to Lydia H. Liu, emancipated women in May Fourth period were a group of people who were trained to be work labour to contribute to the national construction (Liu, 1993). Resultantly, the construction of new woman is secondary to the project of national modernisation under this paradigm.

Moreover, given that China's modernisation also sought to subsume female liberation within its processes, the feeble position of the nation was considered as exemplified by the position of females during the May Fourth era. In the article "On the weakness of China and women's responsibility" (Lun Zhongguo zhi shuairuo nüzi bude ci qizui，論中國之衰弱女子不得辭其处), Hu Bin wrote that “From now on, all the women like me will regard the disasters of China as their own, and the corruption of China as their own" (Hu, 1995, p. 403). The notion of China's feebleness was conflated with the responsibility of females, thus positioning them in relation to the nation's own corruption and catastrophes (Larson, 1998). During the May Fourth era, the group within society considered to be in the most underprivileged position was females. The underdeveloped position of China and its future was associated with the future of women. Consequently, China would progress if females in China also saw an improvement in their social standing. Ultimately, China's modernisation was the overarching frame within which the liberation of females in China occurred.

\section{The New Woman and Male-dominated May Fourth Discourse of Modern Identity}

In The Heart of Women, Chunshi and Supu's relationship is the primary focus. When Supu was 17, she was married to Heshi. Heshi went to Europe to continue his education following Supu giving birth to their daughter. However, Supu began an affair with Chunshi after meeting him, subsequently divorcing Heshi following a certain amount of trepidation and moving to America with Chunshi. Although their period living in America was a positive experience, upon moving back to China the couple were faced with rumours and conjecture, resulting in Supu separating from Chunshi. However, Chunshi sends a letter to Supu which fortifies her; she seeks God's blessings for their relationship towards the close of the book.

Although this novel intends to address the new woman concept, the new woman in this novel is dominated by 
the May Fourth discourse of modern identity, which omits and obfuscates females' personal perspectives. Indeed, the character of the new citizen is the central topic of The Heart of Women, which the new citizen's challenges being equivalent to those of the new woman. Furthermore, without language and culture, women are still absent in the formulation of modern identity. The male-dominated discourse is the only outlet for female authors.

Named as The Heart of Women, this novel originally intended to focus on the challenges facing the new woman. However, the exploration of the protagonists' predicament in this novel excludes women's narratives, contributing to the construction of new citizen rather than new woman. In this novel, most female characters are middle-class intellectuals. According to Dai Jinhua, instead of their gender, their class is the most significant aspect of these women's identity (Dai, 2004). In this sense, it is not gender but class which is the core focus of The Heart of Women. Lu Yin describes the predicament in relation to Supu's journey towards becoming a new woman; however, the same predicament is also posed to Heshi.

Traditional moral principles and virtue continue to restrict Heshi and Supu, despite having travelled to America to continue their education. Upon their return to China, Supu breaks up with Chunshi. It is in part due to the opinions of others in her community. The primary reason for her trepidation about seeking romantic love is that she has internalized traditional moral principles. Heshi refuses to wed Supu again because he cannot tolerate the fact that she has lived with another man for over two years. Supu faces social judgements that are not inflicted on Heshi, due to him being a male. Nevertheless, Heshi does not gain the true freedom in romantic love either. Like Supu, he has also internalized traditional virtue, as he is unable to drop the traditional notion of chasteness.

Furthermore, although Heshi and Supu both claim to be modern citizens, modernity is something that they feel trepidation and depressed about. In The Heart of Women, Heshi is described as melancholy throughout this novel. Although author does not describe Heshi's inner world in detail, readers can still feel the sentimental mood surrounding him. Oscillation and melancholy are also constant companions for Supu. On the one hand, she longs for romantic love. On the other hand, she cannot get rid of the constraint of traditional moral rules. As two "in-between characters" (Larson, 1998), Supu and Heshi live between two cultures - modern culture and traditional culture. They hope to become modern citizens, but they lack the capacity to completely embrace that role. Thus, the new citizens' predicament is exemplified by Heshi and Supu's situation, which ultimately subsumes the predicament facing the new woman in The Heart of Women. Concepts of modern identity eradicate the experiences and voice of females.

Moreover, although Lu Yin contributes to the construction of modern identity through The Heart of Women as a female writer, it is male perspectives rather than women's personal perspectives that provide the channel for this contribution. According to Spivak, culture is the key to the subject being, which can bridge the gap between the subject and the not-yet-subject (Spivak, 1999). Traditionally, culture is something that females have been excluded from building, with males dominating the process. Resultantly, the subject being is an unattainable position for women, due to established culture being bereft of females. Patriarchal concepts are still necessary to characterise liberated females in the wake of the feminist movement, despite traditional female roles and features being rejected by the emancipatory project. In the May Fourth era, the construction of the new woman is based on the reversal of traditional female roles. However, the disavowal of female characteristics is in fact the confirmation of male characteristics. As one of the most influential female writers in the May Fourth period, Lu Yin always declares herself a masculine individual: "I am a masculine person. I do not like those girly stuffs since I was a kid" (Lu, 1985, p. 604). Therefore, rather than being a form of female autonomy, the concept of the new woman becomes a replica of masculinity.

Additionally, a distinct language and discourse of females is absent, alongside the deficiency in their subject standing. The subaltern's voice is undermined and replaced by the power subject's voice, with the latter embodying the subaltern's narrative, according to Spivak's analysis in 'Can the Subaltern Speak?' (Spivak, 1994). A lack of voice is bestowed on females due to their status as subalterns. In the women's liberation movement during the May Fourth era, women are represented by male intellectuals. Although there are some female writers such as Lu Yin and Ding Ling, they are doomed to speak a masculine discourse because language is inherently phallocentric, whatever the content and context of it (Felski, 1989). Consequently, the potential for women's narratives is barred, with females' mute status being apparent. Therefore, although The Heart of Women is a discourse of modern citizen created by a female writer, female voices are omitted, with the novel replicating patriarchal narratives in a discussion of the new citizen. Concerning the subject being, the experiences and narratives of females are omitted by Lu Yin, resulting in the new woman being equivalent to a new male.

\section{Chunshi, the Male Exemplar}

In The Heart of Women, Lu Yin creates Supu, Heshi and Chunshi to exemplify three types of modern citizens. 
However, Chunshi, the principal male character, acts as the sole authentic modern citizen in the text, positioning him as the role model for the female protagonist. Romantic love is a foremost component of individual liberation in Chinese novels of the late 1920s and the early 1930s (Larson, 1998). Irrespective of traditional norms, Chunshi expresses unblemished and undying love in The Heart of Women. From a traditional perspective, Supu is not characteristic of a model wife; evidently, she is not virginal, given that Chunshi began a relationship with her while Supu was married to Heshi. Moreover, Chunshi is more committed to their relationship than Supu is, as she decides to return to Heshi to rekindle their relationship following her and Chunshi's return from America. Nevertheless, regardless of Supu's position and perspective, Chunshi dedicates his love to her, forgetting anything else. Chunshi announces to his friend Zhang Lin: "I am willing to sacrifice all I have for pure love" (Lu, 1934).

Furthermore, contributing to the education of China's future generations, thus facilitating China's modernisation and growth as well as the emergence of a new China, is Chunshi's pursuit as an academic. He travels to America to undertake his $\mathrm{PhD}$, then returns to China to teach at a university. Without sorrow and hesitation, Chunshi achieves a modern vision of his own future through pursuing pure love and working to construct new China. Therefore, he acts as an exemplar for the novel's protagonists, being the book's sole authentic modern citizen. Ironically, in The Heart of Women, a novel intends to deal with the new woman theme, the role model is a male character. It is solely through learning from Chunshi that Supu, the main female character, can transition into an authentic modern citizen. This creates an ambivalence in the distinction between developing into a male and developing into a modern citizen.

As the role model in this novel, Chunshi not only exemplifies the way in which such modernity can be strived for, but also tries to assist and encourage Supu to forego established moral principles and boldly pursue modernity. In this sense, he becomes a guide for a woman, falling into traditional patriarchal discourse. In traditional China, the father was the core of the family, with female positions being diminished (Johnson, 1983). According to established gender and family roles, the father figure gave commands to the females in the family.

This patriarchal discourse can be found in traditional Chinese novels. Dai Jinhua points out that the concept of male domination in traditional Chinese novels sees males acting as guides for females (Dai, 2004). In this novel, Chunshu is characterised as Supu's guide. At the beginning, he was Supu's English teacher. Before they went to the USA, Supu felt trepidation due to the traditional virtue principles expected of women. Chunshi implored with Supu that the love they had was valuable above all else, thus encouraging Chunshi. Again, Supu had doubts about their relationship once they returned to China, due to the rumours and conjecture directed at her, ultimately compelling her to break up with Chunshi. Once more, Chunshi sent a number of letters to Supu to reason with her, trying to convince her to forget the perspectives of others, instead focusing on her contentedness and authentic love and leaving behind traditional restraints. In The Heart of Women, the modern citizen is fundamentally shaped by individual emancipation, a major mark of which is romantic love. Supu is guided towards becoming an authentic modern citizen by Chunshi, who inspires her seeking of true love. As the sole authentic modern citizen in The Heart of Women, Chunshi acts as Supu's guide and as an exemplar for different characters, replicating traditional male-dominated concepts.

\section{Conclusion}

During the May Fourth era, female emancipation's central dynamic was the new woman. Nevertheless, in a male-dominated May Fourth discourse, national modernisation was anterior to the new woman movement. Essentially, a new male is born within a woman's body in The Heart of Women, epitomising the new woman. Chunshi, as the central male character, represents the authentic modern Chinese citizen. Resultantly, within this text, the central female character of Supu is guided by Chunshi, as the means through which she is able to become a modern citizen. Furthermore, instead of their own narratives, female engagement is via male narratives, producing a discussion of the new citizen through patriarchal constructs.

The comprehension of liberated females in modern China was profoundly affected by the May Fourth era's development of the new woman. Modernity in China was a pursuit prioritised over challenges relating to gender. The leftist philosophy of Marxism continued to subsume gender during the 1930s. Ultimately, questions of masculinity and femininity were replaced by class issues. The notion that females were able to share half the burden of supporting the sky was a transmutation of the new woman concept, developed in relation to Maoism in China. However, femininity had been entirely eradicated under socialism, which ultimately restricted female identity, as opposed to an authentic manner of female emancipation being shown by this notion.

\section{Conflict of Interests}

The authors declare that there is no conflict of interests regarding the publication of this paper. 


\section{References}

Dai, J. 戴锦华 (2004). Fuchu lishi dibiao: Xiandai funü wenxue yanjiu 浮出历史地表: 现代妇女文学研究 (Come into Being: Study of Modern Women's Literature). Beijing: Zhongguo renmin daxue chubanshe.

Dooling, A. D. (2005). Women's literary feminism in twentieth-century China. New York: Palgrave Macmillan. https://doi.org/10.1057/9781403978271

Felski, R. (1989). Beyond feminist aesthetics: Feminist literature and social change. Cambridge: Harvard University Press. https://doi.org/10.1177/026327689006002003

Feng, J. (2004). The new woman in early twentieth-century Chinese fiction. West Lafayette: Purdue University Press. https://doi.org/10.7771/1481-4374.1251

Funü zazhi 妇女杂志 (The Ladies’ Journal). Shanghai: Shangwu yinshuguan, 1915-1931.

Hu, B. 胡彬 (1995). Lun zhongguo zhi shuairuo nüzi bude ci qizui 論中國之衰弱女子不得辭其各 (On the weakness of China and women's responsibility). In Li Youning 李又宁 and Zhang Yufa 张玉法 (Eds.), Jindai zhonggguo nüquan yundong shiliao: 1842-1911 近代中國女權運動史料 (The History of Feminist Movements in Modern China) (p. 403). Taipei: Longwen chubanshe.

Johnson, K. A. (1983). Women, the family, and peasant revolution. Chicago: University of Chicago Press. https://doi.org/10.7208/chicago/9780226401942.001.0001

Larson, W. (1998). Women and writing in modern China. Stanford: Stanford University Press. https://doi.org/10.1515/9780804764001

Lawson, F. R. S. (2014). Bai Niu and the women of Quyi: Appropriating metaphysical femininity and reclaiming the feminine voice in Republican China. Modern Chinese Literature and Culture, 26(1), 41-70.

Lei, J. (2015). "Natural" curves: Breast-binding and changing aesthetics of the female body in China of the early twentieth century. Modern Chinese Literature and Culture, 27(1), 163-223.

Liu, H. (1993). Invention and intervention: The female tradition in modern Chinese literature. In T. E. Barlow (Ed.), Gender politics in modern China: Writing and feminism (pp. 33-57). Durham: Duke University Press. https://doi.org/10.1515/9780822396840-004

Liu, H. Y. 刘慧英 (2008). Cong xin qingnian dao funü zazhi 从 《新青年》到《妇女杂志》(From New Youth to The Ladies' Journal). Zhongguo Wenhua Yanjiu, 57(1), 118-126.

Lu, Y. 庐隐 (1934). Nüren de xin 女人的心 (The Heart of Women). Shanghai: Sishe chubanshe.

Lu, Y. 庐隐 (1985). Lu Yin xuanji 庐隐选集 (Anthology of Lu Yin). Fuzhou: Fujian renmin chubanshe.

Mao, D. 茅盾 (1934). Lu Yin lun 庐隐论 (On Lu Yin). In Xiao Feng 肖凤, Lu Yin zhuan 庐隐传 (Biography of Lu Yin) (pp. 137-145). Beijing: Beijing shifan daxue chubanshe.

Mao, D. 茅盾 (1987). Shangwu yinshuguan bianyisuo he gexin xiaoshuo yuebao de qianhou 商务印书馆编译 所和革新《小说月报》的前后 (Commercial Press and the Renovation of Novel Monthly). In Chen Yuan 陈 原 (Ed.), Shangwu yinshuguan jiushinian 商务印书馆九十年 (Shangwu yinshuguan’s Ninety Years) (pp. 162-169). Beijing: Shangwu yinshuguan.

Spivak, G. C. (1994). Can the subaltern speak? In P. Williams \& L. Chrisman (Eds.), Colonial discourse and post-colonial theory: A reader (pp. 66-111). New York: Routledge. https://doi.org/10.4324/9781315656496

Spivak, G. C. (1999). A critique of postcolonial reason: Toward a history of the vanishing present. Cambridge: Harvard University Press. https://doi.org/10.2307/j.ctvjsf541

Xie, J. Z. 谢菊曾 (1983). Shili yangchang de ceying 十里洋场的侧影 (The Profile of Miles with Foreign). Guangzhou: Huacheng chubanshe.

Zhang, Y. L. 张艳玲 (2016). Wusi shiqi funü zazhi bianji sixiang, neirong, tili zhi yanbian 五四时期《妇女杂 志》编辑思想、内容、体例之演变 (The Change of Thought, Content, and Structure of The Ladies'Journal in May Fourth Period). Zhonghua Nüzi Хиеуиаn Xиеbao, 28(1), 93-100.

\section{Copyrights}

Copyright for this article is retained by the author(s), with first publication rights granted to the journal.

This is an open-access article distributed under the terms and conditions of the Creative Commons Attribution license (http://creativecommons.org/licenses/by/4.0/). 